\title{
PHOTODYNAMIC INACTIVATION OF HUMAN DENTAL BIOFILM ISOLATED STREPTOCOCCUS MUTANS WITH 2 PHOTOSENSITIZERS - AN IN VITRO STUDY
}

\author{
Maya Doychinova ${ }^{1}$, Vesselin Kussovski ${ }^{2}$, Tsvetan Tonchev $^{1}$, Slavcho Dimitrov ${ }^{1}$ \\ ${ }^{1}$ Faculty of Dental Medicine, Medical University of Varna, Bulgaria \\ ${ }^{2}$ Bulgarian academy of science, Stephan Angelov Institute, Bulgaria
}

\begin{abstract}
PURPOSE: The aim of this study is to compare the in vitro antimicrobial effect of 2 photosensitizers: FotoSan medium and ZnPcMe on Streptococcus mutans - biofilm isolated clinical stain

MATERIALS AND METHODS: Twelve patients were instructed to restrain from oral hygiene for 24 hours. Plaque was collected with sterile dental floss, placed in a vial containing $3 \mathrm{ml}$ of BFS. Ten-fold dilutions of the suspension were made. $0.1 \mathrm{ml}$ Samples were plated on Mitis Salivarius agar (1). Bacteria were Gram stained as well and underwent morphological identification. A bacterial suspension at a density of $10^{6}$ cells $/ \mathrm{ml}$. was used. An incubation mixture of $1 \mathrm{ml}$. bacterial suspension $\left(10^{6} \mathrm{Cl} . / \mathrm{ml}\right.$.) and the corresponding PS was prepared, achieving a different final concentration of PS. LED light source with a wavelength of 643 $\mathrm{nm}$ was used for irradiation. Samples and controls for each tested PS after $24 \mathrm{~h}$ incubation at $37^{\circ} \mathrm{C}$ were reported.

RESULTS: The control samples in dark showed a minor antimicrobial effect. Samples of bacterial suspension + PS + light irradiation expressed a pronounced antibacterial effect on Streptococcus mutans with small differences in the 2 tested PSs.

CONCLUSIONS: The clinical strain Streptococcus mutans was susceptible to photodynamic inactivation by the two used photosensitizers: FotoSan medium and $\mathrm{ZnPcMe}$. Dark toxicity is to be neglected. ZnPcMe should undergo further trials and given the positive photodynamic effect in vitro, to be licensed for clinical use. FotoSan medium should undergo further in vivo and in vitro experiments in order to establish an alternative protocol for caries prevention.
\end{abstract}

Keywords: antibacterial photodynamic therapy, dental caries prevention, Streptococcus mutans

\section{INTRODUCTION}

The World Health Organization defines dental caries as "a localized, post eruptive, pathological process of external origin involving softening of the hard tooth tissue and proceeding to the for-

Address for correspondence:

Maya Doychinova

17 Odrin Str.

9000 Varna, Bulgaria

e-mail:mayunid@yahoo.com

Received: December 30, 2014

Accepted: March 11, 2015 mation of a cavity" (2). It is a proven fact that dental caries is a multifactorial disease with pandemic spread. Indispensable conditions for the onset and development of a carious lesion are microorganisms, carbohydrate, primarily sucrose, and a susceptible tooth surface $(3,4)$ (Fig. 1). Among all the oral bacteria, Mutans Streptococci colonize the dental surface, contribute largely to the formation of the biofilm matrix and are considered causative agents of dental caries in humans in the presence of fermentable carbohydrates e.g., sucrose and fructose $(5,6)$. Even if not classified as a classic infectious disease, the dental caries entity consists of a presence of cari- 


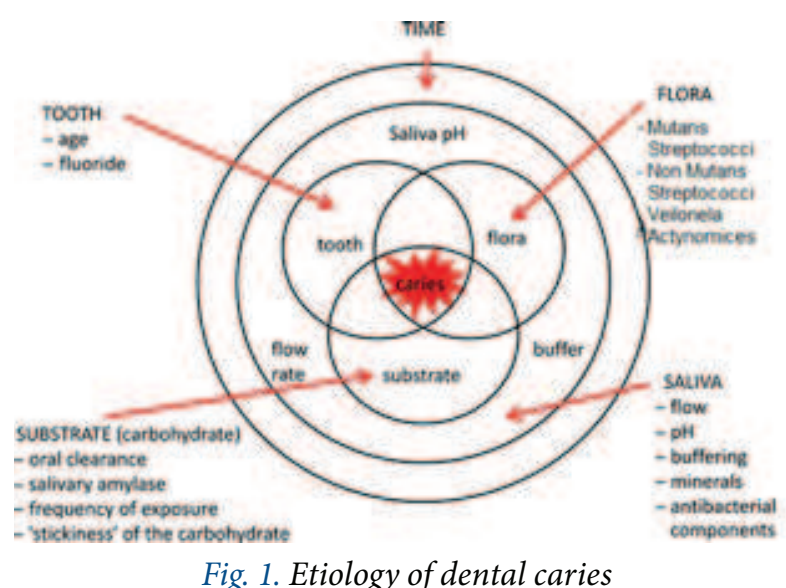

Fig. 1. Etiology of dental caries

ous lesions infected with significant amount of bacteria. Symptomatic treatment is more or less the traditional surgical approach - removing of the defective tissues and their replacement with an alloplastic restorative material. This part of the treatment is indispensable especially in cavitated lesions, but underestimating the utter etiology of the pathological condition, e.g. the infection, in any case stimulates the onset and progression of the process. The importance of bacteria organized in biofilms in the genesis of the carious process is an undeniable fact (2).

Several facts about the etiology of the dental caries have been proven over the years including the fact that sterile teeth in rodents do not decay and also the knowledge that antibiotics such as penicillin, lead to decrease in caries rate and incidence. Conventional antibiotics, even when effective, have proven to express numerous side effects. Given the fact that dental caries is not a classic infectious disease, the use of conventional antibiotics in caries management is not justified. Moreover, biofilm organized bacteria live enclosed in a self-produced polymeric matrix which provides structural stability and protection to the biofilm against adverse environmental conditions, for example, host immunological system and antimicrobial agents $(7,8)$.

Infections caused by biofilm-forming bacteria are often difficult to treat. Biofilm formation almost always leads to a large increase in resistance to antimicrobial agents (up to 1000 -fold decrease in susceptibility) in comparison with planktonic cultures grown in conventional liquid media $(9,10)$. A few mechanisms of biofilm resistance to antibiotics have been proposed. The first proposed mechanism is considering the matrix as a physical and chemical barrier to antibiotics $(11,12)$. Jefferson et al. suggested that even though the matrix may not inhibit the penetration of antibiotics, it may retard the rate of penetration enough to induce the expression of genes within the biofilm that mediates resistance (13).

The second hypothesis explains reduced biofilm susceptibility to antibiotics by the metabolic state of microorganisms in a biofilm. The cells located deep inside the biofilm structure experience nutrient limitation and therefore exist in a slow-growing or starved state (14). Nutrient-depleted zones within the biofilm can result in a stationary phase-like dormancy that may influence the general resistance of biofilms to antibiotics. Slow-growing or non-growing cells are not very susceptible to many antimicrobial agents because the cells divide infrequently and antibiotics that are active against dividing cells (such as beta-lactams) are not effective. The third hypothesis suggests as plausible reason the genetic adaptation to different conditions. Mutation frequency of a biofilm-growing microorganism is significantly higher than that of its planktonic form $(15,16)$.

Dental caries control could be based upon management of disproportionate increase (often site-specific) in the dental plaque content of the Mutans Streptococci being strongly acidogenic and aciduric, Gram positive facultative aerobes $(2,4)$.

We think that alternative ways of controlling the number of Streptococcus mutans in dental biofilms is needed in order to promote better dental health, less carious lesions and less endodontic complications, due to advanced dental caries. This approach could become an alternative to the well spread fluoride prophylaxis of dental caries. Among these alternative antimicrobial methods, the antimicrobial photodynamic therapy (APDT) represents a modern method of choice. APDT consists of three main components: light, a chemical molecule known as a photosensitizer, and oxygen.

The photosensitizer (PS) can be excited by absorbing a certain amount of energy from the light and excitation occurs when the wavelength range of the light overlaps with the absorbance spectrum of the photosensitizer. After excitation, two types of reactions can happen: 
1. Photosensitizers form a long-lived triplet-excited state, from which energy can be transferred to biomolecules.

2. Photosensitizers form a long-lived triplet-excited state, from which energy can be transferred or directly to molecular oxygen (Fig. 2) (20).

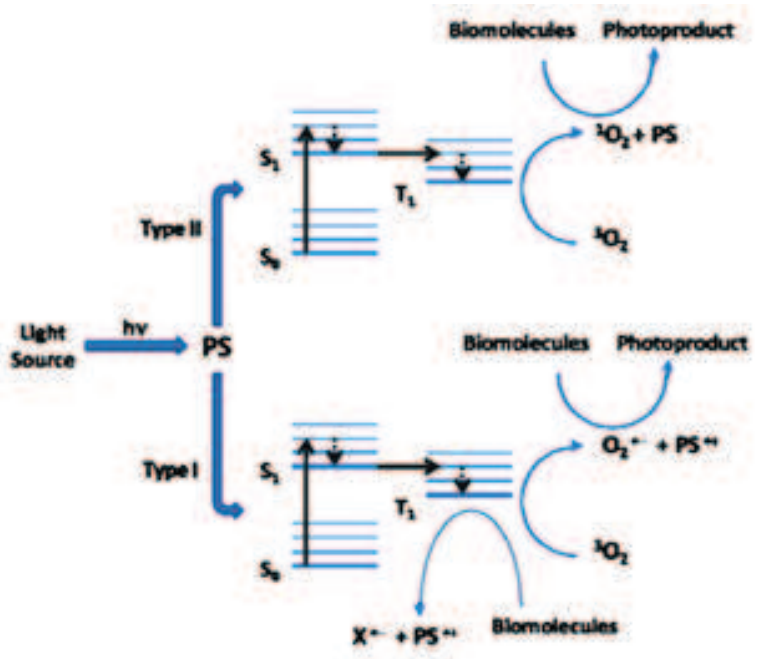

Fig. 2. Mechanisms of ROS generation by combination of light, photosensitizer (PS) and ground-state oxygen. Ground-state photosensitizer (SO) is irradiated with visible light generating excited-state photosensitizer (S1). S1 can relax back to excited-triplet PS state (T1), generating radicals (Type I mechanism) and / or singlet oxygen (Type II mechanism)

The ground-state (triplet) molecular oxygen produces excited singlet-state oxygen, which is a very reactive species with the ability to oxidize biomolecules in the cell such as protein, nucleic acid, and lipids, causing cell damage and death (21). Both mechanisms can operate in the cell simultaneously, but type II is generally considered the major APDT pathway (22). There two major types of cellular damage: DNA damage and the destruction of cellular membranes and organelles. Because the cell is protected by DNA repair systems, DNA damage may not be the main cause of microbial cell death. A large portion of the bactericidal effect of APDT may be due to the disruption of proteins involved in transport and membrane structure and the leakage of cellular contents (23). Recent studies have shown that the antimicrobial effect can be obtained with the use of pho- tosensitizers belonging to different chemical groups. The most studied PSs are phenothiazine dyes (methylene blue (MB) and toluidine blue (TBO), porphyrin and its derivatives, fullerenes, and cyanine and its derivatives. Probably mechanical e. g., application of ultrasound must be used prior to APDT in vivo in order to disrupt the biofilm's structure and thus making the $\mathrm{MO}$ within more susceptible to APDT. In this study we aim to analyze the effect on two different PSs activated with LED generated light on clinically isolated from human dental biofilm, Streptococcus mutans.

\section{MATERIALS AND METHODS}

Sterile dental floss, Vial containing BFS, Mitis salivarius agar, $1 \%$ Telurite, 0.2 units $/ \mathrm{ml}$ bacitracin, FotoSan $-\mathrm{TBO} 180 \mu \mathrm{M}, 90 \mu \mathrm{M}$ and 30 $\mu \mathrm{M}, \mathrm{ZnPcMe}$ - Phthalocyanine zinc (II) complex: 2,9,16,23-tetrakis(3-methylpyridyloxy)phthalocyanine zinc(II) - ZnPcMe -15 $\mu \mathrm{M}, 40 \mu \mathrm{M}$, LED-643nm wavelength, ELO Ltd - Bulgaria. Irradiation's characteristics: power density $100 \mathrm{~mW} / \mathrm{cm}^{2}$ (controlled with photometer Spectra Physics, USA), light dose $12 \mathrm{~J} / \mathrm{cm}^{2}$ (exposure time $-2 \mathrm{~min}$ ) и $60 \mathrm{~J} / \mathrm{cm}^{2}$ (exposure time - $10 \mathrm{~min}$ ), wide-field dissecting microscope.

Selective medium for Streptococcus mutans was prepared by the following prescription: to $1000 \mathrm{ml}$ reconstituted Mitit-salivarius agar, $150 \mathrm{~g}$ of sucrose was added ( $15 \%$ sucrose). The medium was heated to dissolve the components and then autoclaved at $121^{\circ} \mathrm{C}$ for 15 minutes. The medium was then cooled at $45^{\circ} \mathrm{C}$ after which $1 \mathrm{ml}$ of the sterile stock solutions ( $1 \%$ telurite and 0.2 units/ml bacitracin) was added (1).

Dental plaque was collected from 12 people with a sterile dental floss. All participants followed the instructions for discontinued interdental oral hygiene for 24 hours in order for sufficient amount of dental plaque to accumulate interdentally. Forms of informed consent were signed. Professional oral hygiene and instruction for personal oral hygiene were given to each of the participants after collecting of the samples. They were scheduled for control in 7 days.

The dental floss samples were immediately placed in a small screw-capped vial containing $3 \mathrm{ml}$ BMS as transport medium. The vials were agitated on a vortex test tube mixer, for $30 \mathrm{sec}$ in order to dislodge the plaque from floss and to obtain homoge- 
neous suspension. Tenfold dilutions of the suspensions were made in $0.05 \%$ yeast extract water. Duplicate $0.1 \mathrm{ml}$ samples of the dilutions were plated in a selective medium for Streptococcus mutans as described above and spread on the medium. All plates were incubated under $\mathrm{CO}_{2}$ conditions - "candle jar" technique, for 24 hours at $37^{\circ} \mathrm{C}$. After incubation, the plates were allowed to stand at room temperature for 2 hours. The plates were then examined. Two of the samples show no significant Mutans streptococci colonies growth. They were predominated by other bacterial growth like colonies of the enterococci-dark blue to brown and flat, as well as yeast, appearing as large white to light blue matte colonies. The other ten had sufficient colonies of Mutans streptococ$c i$, that underwent further identification being Gram stained.

A bacterial suspension at a density of $10^{6}$ cells/ $\mathrm{ml}$ is used for the needs of antimicrobial photodynamic therapy. Samples of microbial suspensions of each participant were incubated for $20 \mathrm{~min}$ in the dark with:

* $30 \mu \mathrm{M}, 90 \mu \mathrm{M}, 180 \mu \mathrm{M}$ FotoSan

* $15 \mu \mathrm{M}, 40 \mu \mathrm{M}$ ZnMePc

* Controls are as follows:

* bacterial suspension in the dark

* bacterial suspension + PS in the dark-dark toxicity sample

- bacterial suspension + PS + light - true photodynamic sample

Sample: Bacterial suspension (BS) + PS + irradiation. $200 \mu \mathrm{L}$ of the mixture (bacterial suspension + PS), after incubation in the dark for $15 \mathrm{~min}$, were placed in a standard 96-well polystyrene microtiter plate, where the irradiation was performed. LED source with a wavelength of $643 \mathrm{~nm}$ was applied with irradiance of $100 \mathrm{~mW} \cdot \mathrm{cm}^{-2}$ controlled during the experiment by photometer (Spectra Physics, USA). After the needed irradiation, $0.1 \mathrm{~mL}$ samples were taken off and serially diluted (10-fold) with PhosphateBuffered Saline (PBS), pH 7.4, $\left(10^{6} ; 10^{5} ; 10^{4} ; 10^{3} ; 10^{2}\right.$;). Aliquots $(0.025 \mathrm{ml})$ were spread over the prepared selective medium. The number of colonies (CFU) formed on each plate was counted following $48 \mathrm{~h}$ incubation at $37^{\circ} \mathrm{C}$ in $5 \% \mathrm{CO}_{2}$.

Statistics: Each experiment was carried out in duplicate and the data are presented as a mean \pm
Standard deviation (SD). The difference between two means was compared by a two-tailed unpaired Student's $t$-test. The values of $\mathrm{P}<0.05$ were considered as significant.

\section{RESULTS}

Examination of the number of the colonies (CFU) that have grown in Petri dishes serves to analyze the effect of the two PSs subject of our study. The photodynamic inactivation of $10^{6} \mathrm{CFU} \cdot \mathrm{ml}^{-1}$ bacterial suspensions of Streptococcus mutans clinical strain was compared for 2 different PSs-2, 9, 16, 23-tetrakis (3-methylpyridyloxy) phthalocyanine zinc (II) - ZnPcMe and FotoSan- medium. Given the results of our previous study about the photodynamic effect of FotoSan ${ }^{\oplus}$ the used concentrations in this study were $30 \mu \mathrm{M}, 90 \mu \mathrm{M}, 180 \mu \mathrm{M}$. The concentration used for $\mathrm{ZnPcMe}$ were $40 \mu \mathrm{M}$ and $15 \mu \mathrm{M}$. We consider as pilot experiments, the tests done with FotoSan ${ }^{ø}$ medium $180 \mu \mathrm{M}$ and $\mathrm{ZnPcMe} 40 \mu \mathrm{M}$. In both, regardless of the time of irradiation 2,10,15 minutes we observed full photo-inactivation. The samples of bacterial suspension + PS + LED irradiation showed strong antibacterial effect on Streptococcus mutans, clinical strain with small differences in the tested PSs. Dark toxicity was pronounced when $180 \mu \mathrm{M}$ Fotosan was used-4 $\log$ decrease of CFU.ml-1 ${ }^{-1}$ Photodynamic response of bacteria showed full inactivation when treated with concentration of $40 \mu \mathrm{M}$ of $\mathrm{ZnPcMe}$ (at a fluency rate of $100 \mathrm{~mW} \cdot \mathrm{cm}^{-2}$ after $2,10,15 \mathrm{~min}$ irradiation), lack of dark toxicity. The control samples made in dark for the main experiments show negligible dark toxicity at all dye concentrations used $(<0.5 \log$ decrease of viable cells), except for $90 \mu \mathrm{M}$ Fotosan $-(1$ log decrease of viable cells) (Table1, Fig. 3, Table 2, Fig. 4).

\section{DISCUSSION}

The potential of APDT is just beginning to be explored and fully understood. Its possible applications in the management of oral cavity conditions and diseases as an alternative or additional modality for the conventional means and protocols have been confirmed in the late years by numerous studies (24-31). The area of interests includes: endodontic space disinfection, treatment of primary and secondary dental caries, treatment of periodontal acute and chronic conditions, peri-implantitis. We consider as unexplored its plausible and beneficial use in 
Table1. Pilot tests results with FotoSan ${ }^{\circledR} 180 \mu M$, SD-standard deviation, FS-FotoSan ${ }^{\circledast}$, FotoSan ${ }^{\circledast}$ concentration is $180 \mu M$

\begin{tabular}{|c|c|}
\hline Groups & $\begin{array}{l}\text { Number of viable cell Streptococcus Mutans } \\
\left(\text { CFU.ml }{ }^{-1} / \text { mean } \pm \text { SD } /\right)\end{array}$ \\
\hline Bacterial suspension in the dark & $(8.95 \pm 1.78) \times 10^{4}$ \\
\hline Bacterial suspension + FS in the dark & $(1.46 \pm 0.96) \times 10^{3}$ \\
\hline Bacterial suspension $+F S+$ light 2 min & 0 \\
\hline
\end{tabular}

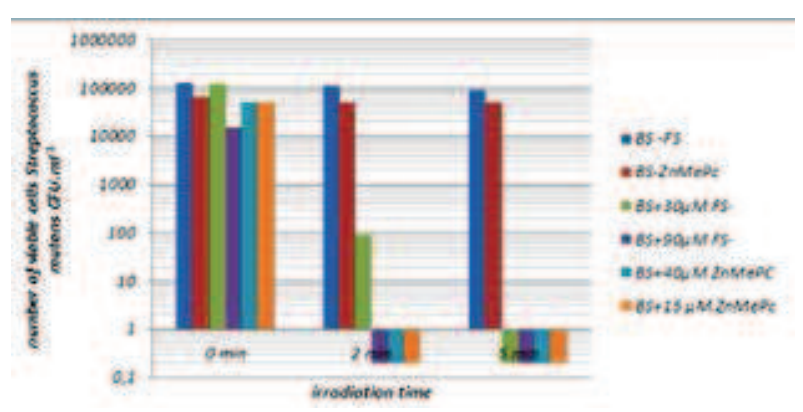

Fig. 3. Photodynamic inactivation of Streptococcus mutans

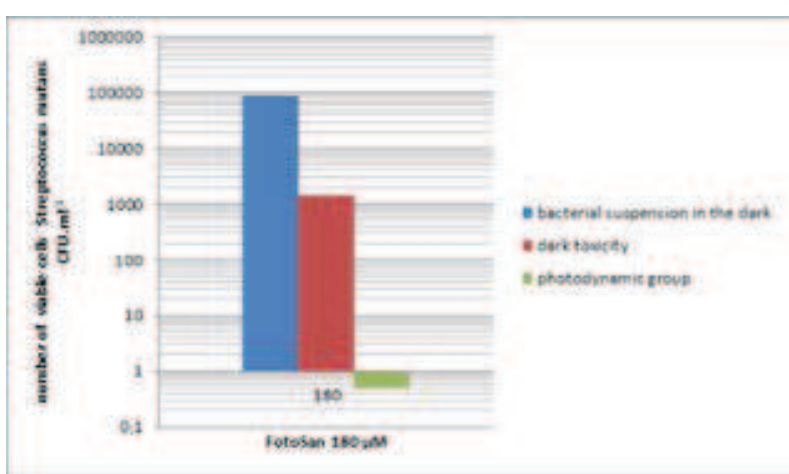

Fig. 4. Pilot tests' results with FotoSan ${ }^{\circledR} 180 \mu \mathrm{M}$

Table 2. Antibacterial photodynamic inactivation results

\begin{tabular}{|c|c|c|c|c|c|c|}
\hline \multirow{2}{*}{$\begin{array}{l}\text { Irradiation } \\
\text { time/sec/ }\end{array}$} & \multicolumn{6}{|c|}{ Number of viable cells Streptococcus mutans (CFU.ml-1/ mean \pm SD/) } \\
\hline & BS - FS & BS - ZnMePc & $\mathrm{BS}+30 \mu \mathrm{M} F \mathrm{~F}$ & $\mathrm{BS}+90 \mu \mathrm{M} \mathrm{FS}$ & $\begin{array}{c}\mathrm{BS}+40 \mu \mathrm{M} \\
\mathrm{ZnMePc}\end{array}$ & $\begin{array}{c}\text { BS with } 15 \mu \mathrm{M} \\
\text { ZnMePc }\end{array}$ \\
\hline 0 & $\begin{array}{c}(1.28 \pm 0.28) \\
\times 10^{5}\end{array}$ & $\begin{array}{l}(6.52 \pm 2.02) \\
\quad \times 10^{4}\end{array}$ & $\begin{array}{c}(1.16 \pm 0.34) \\
\quad \times 10^{5}\end{array}$ & $\begin{array}{c}(1.56 \pm 0.43) \\
\times 10^{4}\end{array}$ & $\begin{array}{c}(4,9 . \pm 1.19) \\
\times 10^{4}\end{array}$ & $\begin{array}{c}(5.10 \pm 1.19) \\
\mathrm{x} 10^{4}\end{array}$ \\
\hline 120 & $\begin{array}{c}(1.14 \pm 0.21) \\
\quad \times 10^{5}\end{array}$ & $\begin{array}{c}(5.10 \pm 2.02) \\
\quad \times 10^{4}\end{array}$ & $\begin{array}{c}(0.93 \pm 0.23) \\
\times 10^{2}\end{array}$ & 0 & 0 & 0 \\
\hline 300 & $\begin{array}{c}(0.91 \pm 0.18) \\
\times 10^{5}\end{array}$ & $\begin{array}{c}(5.00 \pm 2.02) \\
\times 10^{4}\end{array}$ & 0 & 0 & 0 & 0 \\
\hline
\end{tabular}

the field of caries prevention and the management of early, non-cavitated, caries lesions.

Embracing the knowledge that biofilm derived bacteria differ by certain behavioral characteristic, e.g. susceptibility to antimicrobial drugs, from the planktonic and reference strains, we aimed at establishing the effect of APDT on clinic strain Streptococcus mutans. Our target was chosen based on the etiology of dental caries as a multifactorial disease where the presence of acidogenic bacteria is the crucial point leading to demineralization. The disproportional increase of Mutans Streptococci creates not only the $\mathrm{pH}$ needed for initial demineralization, but also contributes in two other directions. On the one hand the drop of $\mathrm{pH}$ initially makes a perfect condition for the flourishing of Mutans Streptococci population, and on the other it gives the chance of other bacteria, non-Mutans Streptococci, Veillonella, and others to gain cariogenic potential thus maintaining and complicating the demineralization process.

The clinical strain Streptococcus mutans showed excellent susceptibility to the 2 PSs used by us in the study. The results are comparable and we consider as contribution the following facts:

1. Even though clinically tested and approved, the FotoSan ${ }^{\bullet}$ medium with active substance tolu- 
Maya Doychinova

idine blue was mostly tested and used with laser light source. In his study we confirmed its excellent photo inactivating ability by inducing photodynamic effect with LED light source. This will make the protocol for caries prevention and management of caries incipiens less expensive and more affordable.

2. The synthesized by us ZnPcMe has no dark toxicity in the used concentrations on Streptococcus mutans clinical strain. The susceptibility of Streptococcus mutans on the other hand when LED light is applied for 5, as well as for 2 minutes is a good base for further clinical tests and trials in order to assess its non-risky in vivo application for caries prevention and early caries management.

\section{CONCLUSION}

Streptococcus mutans clinical strain is susceptible to APDT with FotoSan medium and synthesized by us ZnPcMe. Due to the pronounced dark toxicity at the concentration of $180 \mu \mathrm{M}$, we used a less concentrated suspension of $30 \mu \mathrm{M}$ and $90 \mu \mathrm{M}$, and both showed excellent photodynamic inactivation, regardless of the period for LED irradiation - 2 or 5 minutes.

As far as $\mathrm{ZnPcMe}$ is concerned, the preliminary tests with $40 \mu \mathrm{M}$ showed full photo inactivation. Our goal was to minimize the concentration and to achieve an active concentration for the clinically accepted period of irradiation -2 and 5 minutes. The results show that at $15 \mu \mathrm{M}$ concentration there is full photo inactivation for both time intervals.

Therefore, we consider Fotosan ${ }^{\circledR}$ medium 30 $\mu \mathrm{M}$ and $90 \mu \mathrm{M}$, as suitable for in vivo tests, concerning early plaque formation. The goal of such a study would be to establish an alternative protocol for caries prevention and management of caries incipiens. We consider $\mathrm{ZnPcMe}$ as potential photosensitizer for alternative management of caries incipiens as well as for caries prevention. In our opinion the $\mathrm{ZnPcMe}$ should undergo further trials and, given the positive photodynamic effect in vitro, to be licensed for clinical use. APDT could be incorporated as an alternative or an adjuvant modality in all areas where the side effects of conventional antibiotic therapy and the bacterial resistance to antibiotics are likely to occur.

\section{REFERENCES}

1. Gold O, H Jordan, J van Houte. A selective medium for Streptococcus mutans. Archs Oral Biol, 1973;18(11):1357-1364.

2. Lundeen FT, MT Roberson. The Art and science of operative dentistry. Senior ed., C. Sturdevant, 3rd ed., St. Louis Mosby, 1995, chp.3, 69-72.

3. Wilkins ME. Clinical Practice of the Dental hygienist. Executive editor Sh. Zinner, 7th Ed., Williams\&Wilkins, 1994.

4. Limeback H, J Juan Lai, G Bradley, C Robinson. Comprehensive Preventive Dentistry, 1st ed., Wiley-Blackwell, 2012, chp.1, 9.

5. Loesche W. Role of Streptococcus mutans in human dental decay. Microbiol rev, 1986;50(4):353-380.

6. Hamada S, HD Slade. Biology, immunology, and cariogenicity of Streptococcus mutans. Micorbiol rev, 1980;44(2):331-384.

7. Taraszkiewicz A, G Fila, M Grinholc, J Nakonieizna. Innovative strategies to overcome biofilm resistance. BioMed Research Int, article ID: 150653, 2013.

8. Hoiby N, T Bjarnholt, M Givskov, S Molin, O Ciofu. Antibiotic resistance of bacterial biofilms. Int Journal of Antimicrobial Agents, 2010;35(4):322-332.

9. Costerton CB, PS Stewart, EP Greenberg. Bacterial biofilm: a common cause of persistent infection. Science, 1999;284(5418):1318-1322.

10. Costerton JW, Introduction to biofilm. International Journal of Antimicrobial Agents, 1999;11(3-4):217-221.

11. Ciofu O, LF Mandsberg, H Wang, N Hoiby. Phenotypes selected during chronic lung infection in cystic fibrosis patents: implications for the treatment of Pseudomonas aeruginosa biofilm infections. FEMS Immunology and Medical Micorbiology, 2012;65(2):215-225.

12. Anderl J, J Zahller, F Roe, P Stewart. Role of nutrient limitation and stationary - phase existence in Klebsiella pneumonia biofilm resistance to ampicillin and ciprofloxacin. Antimicrobial Agents and Chemotherapy, 2003;47(4):1251-1256.

13. Jefferson K, D Gldman, G Peir. Use of confocal microscopy to analyze the rate of vancomycin penetration through Staphylococcus aureus bio- 
films. Antimicorbial Agents and Chemotherapy, 2005;49(6):2467-2473.

14. Brown M, D Allison, P Gilbert. Resistance of bacterial biofilms to antibiotics: a growth- rate related effect? J of Antimicorbial Chemotherapy, 1988;22(6):777-780.

15. Driffild K, K Miller, J Bostock, A O’Neill, I Chopra. Increased mutability of Pseudomonas aeruginosa in biofilms. J of Antimicrobial Chemotherapy, 2008;61(5):1053-1056.

16. Yadav M, S Kwon, C Gho, S Park, S Chae, J Song. Gene expression profile of early in vitro biofilms of Streptococcus pneumoniae. Microbiology and Immunology, 2012;56(9):621-629.

17. Ammoechi BT, S Higham. In vitro remineralisation of eroded enamel lesions by saliva. Journal of Dentistry, 2000;29(5):371-376.

18. Herlbutt M, B Novi, D Young. Dental caries $\mathrm{pH}$ mediated disease. Journal of the CDHA, 2003;25(1):234-238.

19. Pretty J, Caries detection and diagnosis: Novel technologies. Journal of dentistry, 2006;34(10):727-739.

20. AX Ragàs. Singlet Oxygen in Antimicrobial Photodynamic Therapy: Biological effects, Mechanistic Studies and Future Directions. Doctoral thesis, Bracelona, Universitat Ramon LLull, 2001.

21. Wainwraight $\mathrm{M}$, Photodynamic antimicrobial chemotherapy (PACT). Journal of Antimicorbial Chemotherapy, 1998;42(1):13-28.

22. Hamblin M, T Hasan. Photodynamic therapy: a new antimicrobial approach to infectious deseases? Photochemical and Photobiological Sciences, 2004;90(5):436-450.

23. Grinholc M, B Szramka, J Kurlenda, A Graczyk, K Bielawski. Bactericidal effect of photodynamic inactivation against methicillin- resistant and methicillin susceptible Staphylococcus aureus is strain dependent. Journal of Photochemistry and Photobiology B, 2008;90(1):57-63.

24. Paulino PT, K Ribeiro, G Thedei Jr, A Tedesco, P Ciancaglini. Use of hand held photopolymerizer to photo inactivate Streptococcus mutans. Archs Oral Biol, 2005;50(3): 353-359.

25. 25. Bevilacqua IM, RA Nicolau, S Khouri, A Brugnera Jr, GR Teodoro. The impact of photodynamic therapy on the viability of Streptococ- cus mutans in a planktonic culture. Photomedecine and Laser therapy, 2007;25(6):513-518.

26. Pereira CA, R Romerio, A Costa, A Machado, J Junqueira, A Jorge. Susceptibility of Candida albicans, Staphylococcus aureus, and Streptococcus mutans biofilms to photodynamic inactivation: an in vitro study. Lasers Med Sci, 2011;26(3):341-348.

27. Rolim J, M de-Melo, S Guedes, F Albuquerque-Filho, J de Souza, N Nogueira, I Zanin, L Rodrigues. The antimicrobial activity of photodynamic therapy against Streptococcus mutans using different photosensitizers. J Photochem Photobiol B, 2012;106:40-46.

28. Araujo N, C Fontana, V Bagnato, M Gerbi. Photodynamic effects of Curcumin against cariogenic pathogens. Photomed Laser Surg, 2012;30(7):393-399.

29. Freire M, I Decastro, C Paulo, M Maria, F Eduardo, S Viviane. Applicability of antimicrobial photodynamic therapy in dentistry. Archs F Oral Science and Research, 2012; 2:88-93.

30. Mantareva V, V Kussovski, I Angelov, D Wohrle, R Dimitrov, E Popova, S Dimitrov. Non-agregated Ga(III)-phtalocyanines: synthesis and photodynamic effect on pathogenic microorganisms planktonic and biofilm cultures. Photochem Photobiol Sci, 2011;10(1):92-102.

31. Vahabi S, R Fekrazad, S Ayremlou, S Taheri, N Zangeneh. The Effect of Antimicrobial Photodynamic Therapy with Radachlorin and Toluidine Blue on Streptococcus mutans: An in vitro Study. J Dent, 2011;8(2):48-54. 